\title{
BEST ESSAY WRITING AND ESSAY WRITING TECHNIQUES IN ELEMENTARY SCHOOL
}

\author{
Nodira Nazarkulovna Eshmanova
}

Teacher, Chirchik State Pedagogical Institute Of Tashkent Region, Uzbekistan

ABSTRACT

The article analyzes the most important of them in the practice of Uzbek pedagogy, the development of the skills of writing essays and essays among primary school students and when familiarizing themselves with the laws of the Uzbek language, the implementation of the selection procedure and orientation by disciplines.

KEYWORDS:- Emotion, mental ability, independent thinking, text comprehension, memory, analysis, writing, assessment, essay, statement, optimal, method, internet, technology, thought, logic, expression, learning, environment, scientific, pedagogical , psychological, physiology, value, physical, mental.

\section{INTRODUCTION}

It is important to build a new stage of development of Uzbekistan, the Third Renaissance. In this process, strategic tasks were set for the development of primary education. The main of these tasks are:

- to determine the interests and abilities of children from primary school;

- Introduction of a system of continuing education of primary school students in specialized classes in the future;

- Implementation of the procedure for selection and orientation of 4th grade graduates in subjects from the 2022-2023 academic year.

These are completely new tasks, and essay and essay writing teaching aids also play an important role in their implementation. Because, according to our approach, as justified above, essay and narration are important tools in shaping the emotional, mental ability, independent thinking, text comprehension, memory, analysis, written speech, and evaluation skills of 7-11 year old students. It is easy to identify the interests and abilities of primary school students with such skills, to select them for teaching in specialized classes, and to direct them in subjects. In this sense, over the years, the experience of Uzbek pedagogy has formed the optimal methods of writing essays and essays, and here we draw your attention to the analysis of the most important of them.

The word "optimal" is Latin and means "convenient", "acceptable", the term means "coordinated, most convenient and expected effective educational process." The word "method" is also Latin and means "way of knowledge", "method" and "style", the term means "guidelines for the acquisition of practical and theoretical knowledge in the educational process." In this regard, when we say optimal methods of writing essays and essays, we mean 
convenient and acceptable methods.

In the practice of Uzbek pedagogy there are several optimal methods of writing essays and essays:

1. Fluent writing method. According to this method, elementary school students should be able to write an essay or essay on a topic based on a specific text. To do this, students are taught the following:

- understand the meaning of words and write them correctly;

- correctly connect words and put suffixes correctly;

- to express the idea in the text and make short sentences;

- to get used to writing as figuratively and comparatively as possible;

- correct representation of letters (such as distinguishing the letters " $\mathrm{h}$ " and " $\mathrm{x} "$ ).

Primary school students are required to master these skills with the help of the Teacher. In this case, students do not master the method of fluent and beautiful writing as expected.

Nowadays, the development of Internet technologies and their widespread use by students aged 7-11 makes it sometimes difficult to master the method of fluent writing. Because many words are misspelled on the Internet, there are cases of writing in dialect and spelling rules are not followed. And students are learning to write them that way.

2. The method of expressing an idea in logic. According to this method, the essay and essay written by the primary school student must logically express their ideas. Students will be taught the following:

- feel the text or statement;

- be able to express an idea in short words;
- have the ability to write;

- try to think independently;

- have sufficient vocabulary;

- take an interesting approach to writing;

These skills are learned from lesson to lesson with the help of the teacher. There are cases where some students read a lot and have enough vocabulary, but find it difficult to express their thoughts in written logic. In such cases, students are required to work individually with each student as much as possible.

3. Narrative method. Under this method, elementary students are required to provide a written story of a suggested plan or topic in essay and essay writing. Therefore, in these matters, students are required to have:

- deep imagination of the text or topic;

- be able to express an opinion in a planned way;

- highlight the main aspects of the text or topic;

- be able to use details and punctuation;

- interesting writing;

These skills will be tested by a teacher. Teaching elementary students to tell stories through essays and essays is an important achievement. Because it reflects the knowledge, skills and abilities of the student. Their sense of creativity develops precisely through the ability to tell a written story.

4. Creative writing method. According to this method, primary school students must write an essay and a statement creatively. To do this, primary school students need to get used to:

- independent approach to the text or topic;

- creative coverage of the text or topic;

- interesting expression of written speech;

- interest of others;

- independent thinking; 
These skills are taught to students by the teacher. These skills must be mastered by primary school students. Otherwise, the creative writing method and written speech in students will not be formed as expected.

After all, these optimal methods of essay and essay writing are required to be mastered by students aged 7-11. Because these methods are important for the purposeful development of primary education during the Third Renaissance, the formation of primary school students in the expected level of skills such as knowledge, thinking, creativity, emotion, mental ability and written speech. These optimal methods are perceived as follows:

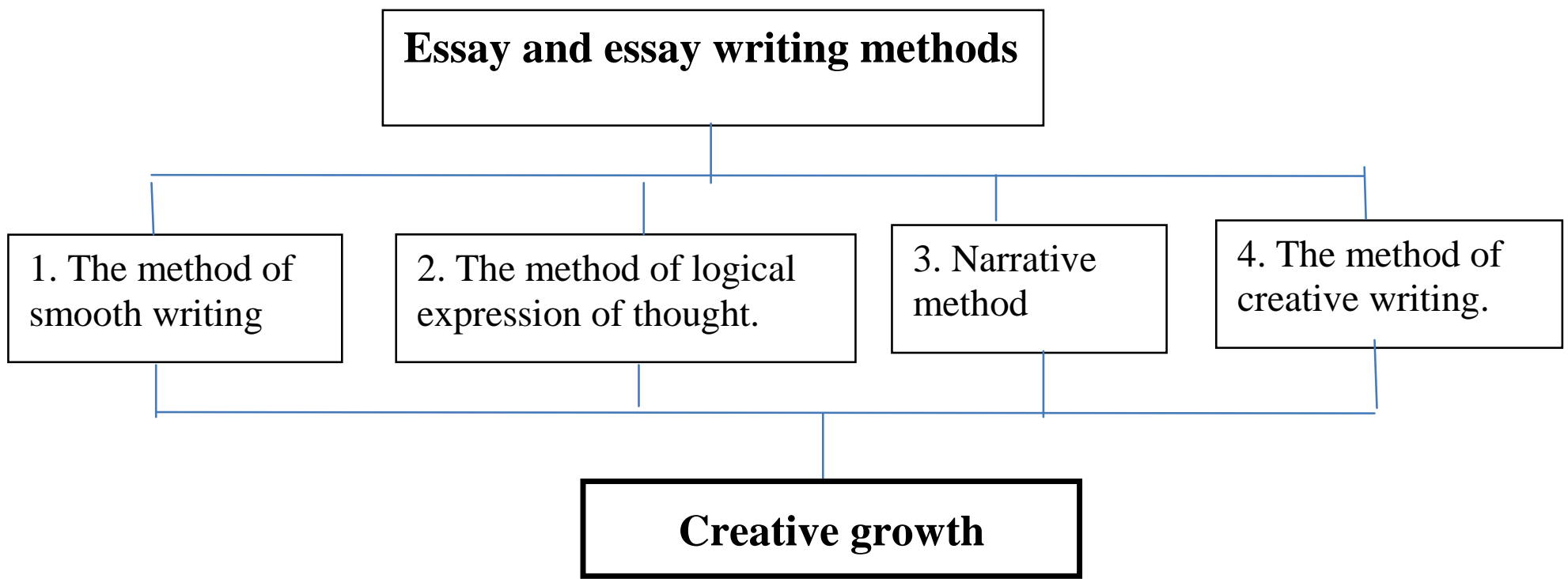

Figure 1.2.1: Optimal methods of essay and essay writing in primary school.

Based on these optimal methods, primary school students should be trained to write essays and essays. For this purpose, specific recommendations are presented in world pedagogy. According to him, it is necessary to take into account the physical capabilities of students aged 7-11, to create a unique learning environment and deal with them individually. We draw your attention to the analysis of these approaches.

1. The question of physical capacity. Primary school students at the age of 7-11 are primarily characterized by physical development. That is why the Russian pedagogical scientist N.K. Krupskaya said in the 20s of the XX century: Without it, the teacher will not be able to properly develop the child's body. Therefore, in the twentieth century, educators, psychologists and physicians have developed and recommended the following indicators of physical development of primary school students: 
CURRENT RESEARCH JOURNAL OF PEDAGOGICS 2(10): 190-195

October 2021 DOI: https://doi.org/10.37547/pedagogics-crjp-02-10-34

ISSN 2767-3278

(C)2021 Master Journals

Crossref doi) 81 Google

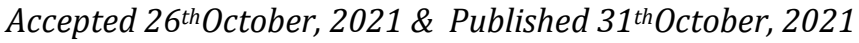

Table 1.2.1

\begin{tabular}{|c|c|c|}
\hline \multicolumn{3}{|l|}{ Boys } \\
\hline age & Height $(\mathrm{cm})$ & Body weight $(\mathrm{kg})$ \\
\hline 7 years old & $117,3-127,3$ & $20,4-28,8$ \\
\hline 8 years old & $121,5-131,1$ & $22,2-30,4$ \\
\hline 9 years old & $126,2-136,2$ & $24,9-33,4$ \\
\hline 10 years old & $130,9-141,5$ & $26,7-37,6$ \\
\hline 11 years old & $133,9-145,4$ & $28,8-38,7$ \\
\hline \multicolumn{3}{|l|}{ Girls } \\
\hline 7 years old & $115,9-126,9$ & $20,3-28,0$ \\
\hline 8 years old & $120,3-131,7$ & $21,3-29,8$ \\
\hline 9 years old & $124,8-136,5$ & $24,2-34,1$ \\
\hline 10 years old & $130,0-142,9$ & $26,0-38,7$ \\
\hline 11 years old & $134,2-146,1$ & $29,1-39,2$ \\
\hline
\end{tabular}

This scientific-methodical recommendation has a special character and should be used in essay and essay writing. Because Essay and Statement writing is primarily a physical assignment for an elementary school student. Therefore, the choice of text for the essay and the statement, the determination of the scope of words and the amount of time should be based on this recommendation. Because a child's brain works and receives information precisely in relation to its physical development.

1. The issue of learning environment. The modern primary education environment is organized on the basis of scientific, pedagogical, psychological and physiological values. At the same time, the use of the Essay and Narrative teaching tool requires the creation of an learning environment based on the principles of freedom, convenience and fun. According to him, the child should be able to freely master the text or topic chosen for the Essay and Narration, to write in a comfortable environment as he wants, and to approach the written work with interest.

International pedagogical practice recommends organizing lessons in grades 1-2 on the basis of tools such as games, and gradually reducing the number of games in grades 3-4. In this regard, it is recommended to write essays and essays in grades 2-4. This means that the learning environment at each class stage should be organized based on the physical, mental and intellectual capabilities of the primary school students. For example, in international pedagogical practice, the following recommendations are given for a table and chair depending on the height of the child. 
Table 1.2.2

\begin{tabular}{|c|c|c|c|}
\hline Child's height $(\mathrm{cm})$ & Table height $(\mathrm{cm})$ & Chair height $(\mathrm{cm})$ & Depth of chair $(\mathrm{cm})$ \\
\hline $110-119$ & 52 & 32 & 27 \\
\hline $120-129$ & 57 & 35 & 29 \\
\hline $130-139$ & 62 & 38 & 29 \\
\hline $140-149$ & 67 & 41 & 34 \\
\hline
\end{tabular}

In our opinion, it would be expedient to follow this international pedagogical recommendation in creating a learning environment for essay and essay writing.

1. The issue of individual engagement. "Individual training" is a form of training in which the teacher has an individual pedagogical impact on the student. It is important to work with each student as individually as possible when doing essay and essay writing. This is because some students may not be able to quickly grasp the suggested text or topic from the content, some may not be able to express their opinion as they wish, or many may find it difficult to begin writing freely. Therefore, the teacher is required to individually prepare each student to write an essay and statement. To do this, it is recommended to follow the following:

- identify the problem that each student has difficulty writing an essay or statement;

- increase student interest;

- to know the character of the student;

- Development of individual abilities of the student.

All of this will be individual to each student. For this reason, the teacher is required to engage as individually as possible with each elementary student in developing essay and essay writing skills.

After all, the application of optimal methods of writing essays and essays to primary school students is at the forefront of the requirements of modernity, convenience and efficiency. Therefore, the physical abilities of students, the learning environment and individual engagement play an important role in this. This, of course, imposes a wideranging task on the teacher. In order to achieve this, it is expedient to rely on Uzbek and international pedagogical experience. To this end, it is important to equip future primary school students in higher pedagogical education institutions with innovative approaches, tools and technologies.

\section{REFERENCES}

1. Address by the President of the Republic of Uzbekistan Shavkat Mirziyoyev on the occasion of Teachers 'and Coaches' Day. // hitp.www. ZiyoNet.uz.2020 October 1

2. Dictionary of pedagogical terms. Developers R. Djuraev, R.Safarova and others.- T: "Science" .2008. Page 90

3. Methods of teaching the native language. 
CURRENT RESEARCH JOURNAL OF PEDAGOGICS 2(10): 190-195

October 2021 DOI: https://doi.org/10.37547/pedagogics-crjp-02-10-34

ISSN 2767-3278

(C)2021 Master Journals

Crossref do: 81 Google

Accepted 26 $6^{\text {th }}$ October, 2021 \& Published $31^{\text {th }}$ October, 2021

Kasimova K. and others.-T: "Nosir". 2009.

Xudayberganova M. From the collection

of statements.-T: "Teacher". 1996

4. Bordovskaya N., Rean A. Pedagogy. - SPb., 2001

5. Shomirzayev, M. K. (2020). The concept of pedagogical technology and basic principles. ACADEMICIA: An International Multidisciplinary Research Journal, 10(11), 1551-1560. 